\title{
Influencing Factors on Knowledge Management for Organizational Sustainability
}

\author{
Mila Kavalić $^{1, *\left(\mathbb{D}, \text { Milan Nikolić }^{1}(\mathbb{D}) \text {, Dragica Radosav }\right.}{ }^{1}$, Sanja Stanisavljev ${ }^{1}\left(\mathbb{D}\right.$ and Mladen Pečujlija ${ }^{2}$ (i) \\ 1 Technical Faculty “Mihajlo Pupin”, University of Novi Sad, 23000 Zrenjanin, Serbia; mikaczr@sbb.rs (M.N.); \\ radosav@tfzr.uns.ac.rs (D.R.); sanja@tfzr.uns.ac.rs (S.S.) \\ 2 Faculty of Technical Science, University of Novi Sad, 21000 Novi Sad, Serbia; pecujlija@gmail.com \\ * Correspondence: mila@tfzr.uns.ac.rs; Tel.: +381-611400314
}

check for

updates

Citation: Kavalić, M.; Nikolić, M.; Radosav, D.; Stanisavljev, S.; Pečujlija, $\mathrm{M}$. Influencing Factors on Knowledge Management for Organizational Sustainability. Sustainability 2021, 13, 1497. https://doi.org/10.3390/ su13031497

Received: 22 December 2020

Accepted: 15 January 2021

Published: 01 February 2021

Publisher's Note: MDPI stays neutral with regard to jurisdictional claims in published maps and institutional affiliations.

Copyright: (c) 2021 by the authors. Licensee MDPI, Basel, Switzerland. This article is an open access article distributed under the terms and conditions of the Creative Commons Attribution (CC BY) license (https:/ / creativecommons.org/licenses/by/ $4.0 /)$.

\begin{abstract}
This paper analyses the level of knowledge management implementation in organizations and the impact of control variables on knowledge management dimensions. In addition, the importance of knowledge management influence on the competitive sustainability of an organization is addressed. The idea of the research is to highlight key factors that affect the effectiveness and efficiency of knowledge management applications in transition conditions. Data for the study were obtained by surveying 520 respondents-managers of all levels from manufacturing enterprises in Serbia. A $t$-test was conducted in several variations. More precisely, the $t$-test analysis was conducted on the average assessments of knowledge management dimensions and with specific control variables. The findings indicate that knowledge management dimensions differ in domestic enterprises and foreign enterprises as well as that their impact differs across organizational levels. Financial performance (profitability, sales growth, asset growth, market share, competitive position in a specific industry, productivity, and salaries) was found to be a reliable indicator of knowledge management success. It can be concluded that knowledge management dimensions have an important role in transition countries, and it is evident that effective knowledge management is imperative for the competitive sustainability of an organization.
\end{abstract}

Keywords: knowledge management; national origin; ownership structure; enterprise size; financial performance; competitive sustainability; transition; Serbia

\section{Introduction}

Sustainable development is a complex and multidimensional process. It has three basic dimensions: economic, social, and environmental. It also requires knowledge to become the basic productive force of society.

Sustainable development is now a source of differentiation, potential competitive advantage, and integrated value creation. Sustainable supply chain management implementation opportunities can be found in both developed and developing country markets. Managers need to focus on comprehensive management including social, economic, and ecological performance. Implementing sustainable solutions in logistics processes will not only help the environment and improve the image of the organization but also can give enterprises financial benefits [1]. Some studies suggest that certified environmental management systems are critical to a firm's ability to improve operation performance [2]. Circular Economy (CE) is regarded as a strategic and relevant issue for profitability and value creation organizations. The level of $\mathrm{CE}$ adoption is positively impacted by the status of Environmental Management System (EMS) certification and the willingness to improve environmental performance and to achieve a sustainable business model [3]. CE enhances firms' competitiveness and mitigates risks without endangering the environment and causing resource scarcity [4]. However, there are several barriers to overcome when aiming for successful adoption of $\mathrm{CE}$, such as the lack of technical and technological knowledge [5]. Resistance to change may arise due to risk aversion, lack of information and knowledge, or 
inaccurate perceptions. [3]. Diverse stakeholders will demand considerable investments in the short term, like additional competencies and knowledge, new contracts, new product and process designs, and new equipment with long-term paybacks [6].

This paper primarily focuses on the importance of adequate knowledge management in order to achieve sustainability in the organization. In this paper, organizational sustainability is analyzed as competitive sustainability of the organization. Further, competitive sustainability affects financial and finally economic sustainability. Economic sustainability refers to the creation of an economic system with a high degree of stability and efficiency that further creates new value. This value represents a source of consumption for society.

The fourth industrial revolution-Industry 4.0-alongside the effects of external forces, such as strong competition and changes in customer demands, together with the economic crisis create serious challenges for enterprises that aim to achieve a competitive position on the market [7]. Strong competitiveness of a country can lead to sustainable economic development, high employment rates, and social cohesion. The European Commission has set competitiveness improvements as the main strategic goal of the Lisbon Strategy. A key component of the Lisbon Strategy is the development and improvement of knowledge. This further implies greater investment in education and training, scientific research, technological research, and innovation. From the five key objectives set by this document, two relate to the improvement of knowledge [8]. The noted economic conditions create strong challenges and require significant agreement from all stakeholders when it comes to efficient knowledge transfer. Acquisition, application, and exchange of knowledge are widely recognized as key components of organizational performance [9]. Transitional market conditions in Serbia impose increasingly dynamic changes and business challenges on organizations. In order to survive, it is necessary to expand knowledge and it is necessary to find the right path towards the sustainability of the organization [10]. Therefore, it is important that organizations develop strategic and competitive advantages based on knowledge. Through the concept of knowledge management (KM), organizations effectively prepare to deal with transitional and turbulent business conditions. The implementation of KM lies in the need to master collective knowledge through continuous learning and continuous improvement. This improvement involves both the organization as a whole and the individuals in it.

$\mathrm{KM}$ is "the fundamental effort of management to use tools and approaches to find, improve, transfer, and apply knowledge and experience that are available in the organization" [11]. Debowski defined KM as "the process of identifying, organizing, and disseminating intellectual property that is critical to the long-term operation of an organization" [12]. According to Wiig, the main goal of KM is "the intelligent sustainability of overall business success and to achieve the best value from the available knowledge resources" [13].

The effects of knowledge management on different organizational outcomes and financial performance are analyzed in numerous studies. High levels of knowledge management promote organizational development and competitiveness [14]. Further, at the macro level, it also contributes to economic growth [15]. Different models, factors, and processes of knowledge management contribute to the overall improvement of business results [16-18]. Financial performance can be directly increased through effective and efficient knowledge management application [19-23]. Additionally, human resource development, pronounced learning ability, as well as quality management of intellectual capital have a positive impact on financial performance [24-28].

Finally, what is important for this study is that some references indicate the connection between knowledge management and competitiveness [29-31] as well as knowledge management and organizational sustainability $[20,30,32,33]$. Based on the previous statements, it is evident that knowledge management is important for achieving, maintaining, and increasing the competitiveness and sustainability of an organization. The modern business environment is dynamic and characterized by constant changes. Knowledge management 
is a catalyst for value creation, and this value has the potential to increase enterprise competitiveness on the market.

Without appropriately knowing the issues of knowledge management and without an appropriate approach to knowledge management, it is almost impossible to ensure organizational sustainability for a long period of time.

Due to the above, conducting research in the field of knowledge management is imperative. Knowledge management influences numerous organizational and individual performances [34-37]; thus, it is very useful to discover what affects knowledge management. The aim of this paper is to examine the effects of several control variables on knowledge management dimensions. More precisely, the influences of the following four control variables are examined: national origin of the enterprise, ownership structure of the enterprise, enterprise size, and financial performance. Existing research shows a significant relation between financial performance and knowledge management [19-22,24,25]. However, the influences of the remaining three control variables (national origin, ownership structure, and enterprise size) on knowledge management have not been examined so far. This lack of previous studies is based on a literature review of the existing studies. Of course, there is a possibility that similar studies have been conducted, but even in that case, it is certain that the number of such studies is neither large nor enough.

The significance of this current paper is precisely that it fills the gap, which refers to a lack of research on the influence of the observed control variables on knowledge management. Insight into these influences will provide a better understanding into the ways and strategies to raise the level of knowledge management in organizations in Serbia. Undoubtedly, such knowledge can contribute to the national competitiveness of the Serbian economy as well as the sustainability of organizations in Serbia. The obtained results can be easily applied analogously in some other countries and economic conditions, especially in transition. In addition, there is always the possibility to do similar research for some desired sample.

In the next section, the theoretical background is provided and the hypotheses are developed. Next, the results of the research and discussions of these results are presented. Further, the results of the descriptive statistics are presented, followed by the $t$-test results. In addition, these results are analyzed in accordance with the proposed hypothesis. Afterwards, the influence of control variables on knowledge management is discussed. Finally, conclusions drawn are from the discussion.

\section{Theory and Hypothesis}

\subsection{Knowledge Management}

Constant changes in today's world require enterprises to adapt and apply their potential in order to effectively face challenges on the market. Knowledge management is a key factor in organizational development. It includes and brings constant competitive dynamics in the enterprise, which sees knowledge as the basic potential for improving productivity [31].

Despite the extensive literature on $\mathrm{KM}$, there is no widely accepted definition of KM $[10,34]$. The review of literature and the analysis of existing definitions of KM showed that some KM definitions are technology-based, while the majority of definitions indicate that KM includes assets, activities, or processes for developing and using knowledge to achieve or improve business metrics. These metrics can be organizational goals, values, long-term performance, and overall success.

Competitive advantage is considered to be the final goal of a strategic plan [38]. Enterprise competitiveness, as part of knowledge management, is closely related to the economic performance of enterprises, and various studies have been conducted on this topic. It can be said that KM process management (i.e., knowledge creation, acquisition, sharing, and implementation) affects the economic aspects of corporate sustainability [33]. Cascella defined the knowledge management process as "all the performance characteristics or attributes of a process needed to achieve a process goal consistently and reliably" [39]. 
Furthermore, KM management processes such as knowledge creation, knowledge sharing, and knowledge application influence organizational culture, structure, strategy, and overall organizational efficiency. In addition, the overall impact of KM on the entire contextual organizational environment is observed [40-43]

KM capabilities are related to business strategy and organizational efficiency [35]. Additionally, KM process abilities are linked to intellectual capital performance, organizational efficiency, and overall competitive advantage [29]. Another study investigated and noted that KM infrastructural capabilities (leadership, culture, KM strategy, and technological capability) can have a direct impact on information technology efficiency and KM process abilities [36].

The concept of knowledge management includes systematic management of processes, methods, and tools with the goal to apply knowledge in strategic goal achievement. In addition, knowledge management applies to efficient decision making and value creation in the organization [44]. In order for sustainable performance in public organizations, it is necessary to maintain and improve employee motivation policies regarding knowledge application [32].

One of the most influential factors for the diverse use of performance measurement is system maturity. This further indicates that most enterprises must actively work on system development and continuously improve and upgrade the system from a technical, organizational, and functional perspective [45]. Knowledge has a key role in adequately upgrading and implementing this system. Knowledge has to be present in all parts of the system. [46]. Knowledge transfer is at a low level of efficiency among project team members in the Serbian banking sector. Organizational understanding, evaluation, and adequate support in the process of knowledge transfer would influence success indicators of knowledge transfer within project teams in the banking industry of Serbia [9].

Organizations that have the ability to manage knowledge will use resources more efficiently and thus will be more innovative and conduct business better [30].

An organizational climate that is based on collaboration is an important factor for effective knowledge management practice implementation. Managers have to establish adequate organizational conditions that enable the successful utilization of knowledge in enterprises. This would further significantly improve the competitiveness on a macro level [30].

When observing the process of Knowledge Exchange (KE), it is said that KE is one of the main drivers of creating social sustainability and is considered to predict high organizational performance and innovation skills [37]. Competitiveness is directly conditioned by the productivity of employees, and the productivity of employees is conditioned by knowledge management. Employee productivity in knowledge is crucial not only for organizational innovation and competitiveness but also for sustainable development. The public sector of various developing countries has developed knowledge management functions in order to solve the problem of low organizational commitment (higher turnover rates) and performance of knowledge workers [20].

\subsection{Knowledge Management and Control Variables}

Knowledge management is closely connected to different variables. It is influenced by various factors. Similarly, the implementation of KM affects a number of factors in organizations. KM creates competitive strength and advantage, which positively affects organizational development, productivity, and the dynamics of competitive ability [31]. The research findings indicate a strong relation between higher education. Additionally, a strong link is noted between the competitiveness of the economy and sustainable development [47]. When looking at the macro level, there is a connection between economic growth and factors such as public expenditure, investments, entrepreneurship, human resources, and knowledge [15].

Knowledge management is statistically significant, positive, and strongly related to financial performance. This result is consistent with most existing research [19-22,30]. 
The economic performance of the enterprise, through competitiveness, is closely related to knowledge management. According to Abbas and Sağsan, the economic aspects of enterprise sustainability are closely related to KM [33]. Furthermore, the results indicate a positive relationship between innovation and competitiveness and economic/financial results [47].

Knowledge enabling factors (KEF) are significantly associated with organizational effectiveness outcomes [16]. Similarly, the knowledge circulation process (KCP) has a statistically significant relationship with financial performance and positive business performance [17]. Enterprises, which have the ability to effectively manage knowledge can use resources more efficiently, can be more innovative, and can thus achieve overall better financial results [30]. In addition, organizational learning positively affects financial results through innovation and competitive advantage [48].

The implementation of knowledge management directly affects improvements in financial performance. This further directly affects the increase in KM levels. The adoption and application of knowledge management improves financial performance of organizations [19]. This further influences the knowledge application process. Knowledge management functions can be applied to solve problems of low organizational commitment, which then results in improved financial performance [20]. High levels of knowledge management contribute to better overall organizational performance, which also includes financial performance [21]. The ability to effectively manage knowledge plays a mediating role between the strategic practices of human resources and financial performance [23]. Financial performance indicators (profitability and productivity) are directly related to intellectual capital performance [24]. There is a statistically significant relationship between human resource efficiency and financial performance [25]. The results also indicate that human resource development is one of the most important factors when it comes to economic success. Therefore, enterprises should focus on human capital or human resources. In financially stable enterprises, the processes of KM implementation are much easier compared to financially struggling enterprises. Prieto and Revilla suggested that there is a positive relationship between learning ability and financial performance [26]. Knowledge management as well as improvements in the performance of intellectual capital maximize financial values [27]. Certainly, it can be argued that there is a connection between intellectual capital and financial performance [28].

\subsection{Hypotheses}

When developing hypotheses, it is useful to consider the state of knowledge management dimensions in enterprises in Serbia, so the initial null hypothesis is related to this issue. Furthermore, since the main goal of this current paper is to examine the influence of the four control variables national origin of the enterprise, ownership structure of the enterprise, enterprise size, and financial performance on knowledge management, four additional hypotheses are set, one for each control variable. It should be noted once more, as stated in the Introduction, that no research has been conducted so far on the influence of three control variables (national origin, ownership structure, and enterprise size) on knowledge management dimensions. Therefore, these impacts are assumed without special prior theoretical considerations in this narrow field. Here, we want to note that the absence of theoretical considerations in this part does not necessarily represent a lack of due diligence when it comes to the theoretical background for this current study. On the contrary, this can be seen as a contribution, precisely because something new is being researched, something that has not been researched so far, or at least has not been done to a sufficient extent.

Therefore, the following five hypotheses are proposed:

Hypothesis 1 (H1). Knowledge management dimensions have high average values in enterprises in Serbia.

Hypothesis 2 (H2). There is a statistically significant difference in the influence of the national origin of an enterprise as a control variable on knowledge management dimensions. 
Hypothesis 3 (H3). There is a statistically significant difference in the influence of the ownership structure of an enterprise as a control variable on knowledge management dimensions.

Hypothesis $4 \mathbf{~ ( H 4 ) . ~ T h e r e ~ i s ~ a ~ s t a t i s t i c a l l y ~ s i g n i f i c a n t ~ d i f f e r e n c e ~ i n ~ t h e ~ i n f l u e n c e ~ o f ~ t h e ~ e n t e r p r i s e ~}$ size as a control variable on knowledge management dimensions.

Hypothesis 5 (H5). There is a statistically significant difference in the influence of financial performance as a control variable on knowledge management dimensions.

\section{Method}

\subsection{Survey Instruments (Measures)}

Knowledge management: in this research, an instrument created by Nguyen (2010) was used to measure knowledge management. The questionnaire provides a global score of knowledge management application. The questionnaire includes 50 items that are classified into 9 dimensions. These dimensions are organizational structure, organizational culture, skills and knowledge of employees, information-technical systems in support of knowledge, knowledge acquisition, knowledge conversion process, knowledge application process, knowledge protection processes, and competitive advantage gained through the application of knowledge. Respondents used a seven-point Likert scale for evaluation [49].

Financial Performance was conceptualized and based on references that analyzed the following items: profitability, sales growth, asset growth, market share, and competitive position in a specific industry [50-52]. In addition to these items, two more have been added: productivity and salaries. In this way, seven financial performance items were formed for this current research. All seven performance items were evaluated via five-point Likert scales, and this method of item evaluation for financial performance is in accordance with the previously mentioned references. A similar valuation approach was applied in the following references [50-52].

\subsection{Data Collection and Sample}

In our research, the respondents filled out anonymous questionnaires. The survey process was conducted via interview. The sample in the research was designed to include managers of all levels in manufacturing companies. First of all, managers represent a group which, by its qualifications and activities, can best assess the level of implementation of knowledge management as well as the factors that affect knowledge management. Also, we considered it adequate to examine managers of all levels because, in that way, a complete and objective picture of the implementation of knowledge management at all levels in the company is obtained. Precisely because we examined various factors that affect the implementation of knowledge management (national origin, ownership structure, company size, and financial performance), the sample was selected from companies of different national origins, ownership structures, sizes, and financial potentials. Thus, the sample faithfully reflects all the important characteristics of the population that we wanted to examine and, at the same time, the characteristics of the company in terms of the observed influential variables. In addition, respondents were committed to expressing attitudes: based on Cronbach's alpha factor values (0.914-0.977), it can be concluded that respondents responded consistently. Finally, a sample size of 520 respondents can be considered appropriate.

The characteristics of the sample are as follows:

- According to the national origin of enterprises, the sample consists of 372 domestic enterprises $(71.5 \%)$ and 148 foreign enterprises $(28.5 \%)$, which are predominantly from the following countries: Croatia, Germany, Australia, and Italy.

- According to the ownership structure of the enterprise, the sample includes 99 state companies (19\%) and 421 private enterprises $(81 \%)$ and enterprises are mostly from the textile industry, chemical-food industry, and automotive industry. 
- According to enterprise size, the sample is divided into two groups: small enterprises—up to 50 employees_-and medium and large enterprises—over 50 employees. The sample includes 300 respondents from small enterprises (57.7\%) and $220(42.3 \%)$ respondents from medium and large enterprises.

- Financial performance as a control variable is based on the value of the financial performance dimension (this dimension includes the following items: productivity, profitability, market share, sales growth, competitive status, asset growth, and salaries). Here, the sample is split at the median value, which for the financial performance dimension is 5286. Thus, in the group of enterprises with higher financial performance (more successful enterprises, FP > 5286), there are 248 enterprises. In the group of enterprises with lower financial performance (less successful enterprises, FP $\leq 5286$ ), there are 272 enterprises.

\section{Results and Discussion}

\subsection{Descriptive Statistics}

The results of descriptive statistics for the knowledge management dimensions are presented in Table 1. Cronbach's alpha values range from 0.914 to 0.977 .

Table 1. Descriptive statistics for the knowledge management dimensions.

\begin{tabular}{|c|c|c|c|c|c|c|c|}
\hline Dimensions & Abbr. & $\mathbf{N}$ & Min. & Max. & Mean & Std. Dev. & $\begin{array}{l}\text { Cron. } \\
\text { Alpha }\end{array}$ \\
\hline Organizational culture & KM1 & 520 & 1000 & 7000 & 430.495 & 1.493443 & 0.940 \\
\hline T-shaped skills: human resources & KM2 & 520 & 1000 & 7000 & 431.154 & 1.558142 & 0.923 \\
\hline Information Technology & KM3 & 520 & 1600 & 7000 & 464.538 & 1.425104 & 0.933 \\
\hline Knowledge acquisition process & KM4 & 520 & 1500 & 7000 & 464.087 & 1.463423 & 0.917 \\
\hline Knowledge conversion process & KM5 & 520 & 1000 & 7000 & 455.897 & 1.527681 & 0.958 \\
\hline The process of applying knowledge & KM6 & 520 & 1000 & 7000 & 453.173 & 1.547751 & 0.967 \\
\hline Knowledge protection process & KM7 & 520 & 1000 & 7000 & 487.885 & 1.373548 & 0.977 \\
\hline Competition advantage & KM8 & 520 & 1000 & 7000 & 446.703 & 1.463921 & 0.961 \\
\hline Organizational culture & KM9 & 520 & 1000 & 7000 & 456.394 & 1.418676 & 0.914 \\
\hline
\end{tabular}

\subsection{Discussing the Results of Descriptive Statistics Analysis (Testing Hypothesis H1)}

Descriptive statistics indicate that knowledge management dimensions in general, have values slightly above the mean value. It can be argued that this is an adequate result. This argument also takes into consideration that the domestic economy is not at a high level in terms of technological development and competitiveness. When other research conducted of Serbia are analyzed, it can be noticed that the transfer of knowledge is not very high [9]. The public sector of various developing countries has developed knowledge management functions to address the problem of low organizational commitment (higher turnover rates) and the performance of knowledge workers [20].

From the knowledge management dimensions, the highest mean value is noted for the KM7 dimension - the process of applying knowledge. It is obvious that Serbian enterprises make high use of their available knowledge. Additionally, due to high mean values, the KM3 dimension-T-shaped skills: human resources-and the KM4 dimensioninformation technology - should be taken into consideration as highly influential dimensions. This indicates that employees have good knowledge and skills, that they are well trained for the systematic use of knowledge, and that they are flexible in mastering new knowledge that is necessary to monitor changes in the environment. Additionally, information technologies are successfully used for communication and acquiring knowledge.

On the other hand, the lowest mean values are noted with the KM1 dimensionorganizational structure and KM2 dimension-organizational culture. Therefore, it can be concluded that enterprises still do not give enough importance to knowledge management or do not understand its importance. Therefore, in Serbian enterprises, the organizational structure is not fully adapted to knowledge management and the organizational culture 
is such that understanding, support, and evaluation of knowledge management are not present in a sufficient amounts.

The results of other studies also coincide with the conclusion that an organizational climate based on collaboration is an important factor for effective implementation of knowledge management practice. Managers also have to establish an adequate organizational environment that would enable successful utilization of knowledge in enterprises. This would further significantly improve competitiveness on a macro level [30].

However, there are positive outcomes as well. The results indicate that knowledge is applied in a significant manner, and human resources have a high level of specialized and systemic knowledge. In addition, information technology is effectively applied in the process of knowledge management. These findings confirms hypothesis H1.

\section{3. $t$-Test (Analyzing the Influence of Control Variable on Knowledge Management Dimensions)}

A $t$-test was conducted on the mean values of all observed knowledge management dimensions. The $t$-tests were in accordance with the observed control variables (national origin, ownership structure, enterprise size, and financial performance). The results are presented in Tables 2-5.

In these tables, the statistically significant differences (based on a given control variable) of the mean estimates of every knowledge management dimension are shaded in bold. Mean estimates of the knowledge management dimensions that are statistically significant and indicate certain statistically significant relations of the Sig. (2-tailed) are shown italics.

\subsection{Discussion of Control Variable Influence on Knowledge Management Dimensions}

4.4.1. The Influence of National Origin on Knowledge Management Dimensions (Testing Hypothesis H2)

When national origin is viewed as the control variable, a statistically significant difference in the mean values of knowledge management dimensions occurs in three dimensions: KM2 —organizational culture, KM6 - knowledge conversion process, and KM9-competitive advantage. In all three cases, higher mean values are noted with foreign enterprises.

It can be concluded that foreign enterprises have an organizational culture which, to a greater extent, understands, nurtures, and supports knowledge management processes. Foreign enterprises value work, training, and learning to a greater extent. In addition, it is expected that employees are more involved in learning and knowledge transfer processes.

Further, foreign enterprises have more pronounced processes for transferring knowledge to individuals within the organization as well as for acquiring knowledge from individuals. Foreign enterprises are better organized for the realization of knowledge management processes as well as in the replacement of outdated knowledge.

Foreign enterprises are able to gain a stronger competitive advantage through knowledge management compared to domestic enterprises. This includes more frequent application of knowledge-based innovations, greater use of knowledge in creating strong barriers for competition, and easier and faster introduction of new products and/or services in the production/service program.

Previous studies conducted in countries with stable economies also point out that knowledge management is a key factor for organizational development. Knowledge management includes and brings constant competitive dynamics in the enterprise. These dynamics see knowledge as the basis for improving productivity [14]. In the other six dimensions of knowledge management, the mean values are similar, with a slight advantage for foreign enterprises. This slight advantage is most pronounced in two dimensions: KM1—organizational structure and KM8 - knowledge protection process. There is no statistically significant difference between these two dimensions (but is close to statistically significant). 
Table 2. $t$-test of mean values of the knowledge management dimensions depending on the national origin (1-domestic; 2 -foreign).

\begin{tabular}{|c|c|c|c|c|c|c|c|c|c|c|c|c|}
\hline \multirow{2}{*}{$\begin{array}{c}\text { KM } \\
\text { Dimensions }\end{array}$} & \multirow{2}{*}{ National Origin } & \multirow{2}{*}{$\mathbf{N}$} & \multirow{2}{*}{ Mean } & \multirow{2}{*}{$\begin{array}{c}\text { Std. } \\
\text { Deviation }\end{array}$} & \multirow{2}{*}{$\begin{array}{l}\text { Std. Error } \\
\text { Mean }\end{array}$} & \multicolumn{2}{|c|}{$\begin{array}{l}\text { Levene's Test for } \\
\text { Equality of Variances }\end{array}$} & \multicolumn{5}{|c|}{$t$-Test for Equality of Means } \\
\hline & & & & & & F & Sig. & $t$ & df & $\begin{array}{c}\text { Sig. } \\
\text { (2-Tailed) }\end{array}$ & $\begin{array}{c}\text { Mean } \\
\text { Difference }\end{array}$ & $\begin{array}{l}\text { Std. Error } \\
\text { Difference }\end{array}$ \\
\hline \multirow[b]{2}{*}{ KM1 } & 1 Domestic & 372 & 423.349 & 1.539 .446 & 0.079817 & \multirow[t]{2}{*}{1.891} & \multirow[t]{2}{*}{0.170} & -1.733 & 518 & 0.084 & -0.251069 & 0.144861 \\
\hline & 2 Foreign & 148 & 448.456 & 1.359 .418 & 0.111743 & & & -1.828 & 303.918 & 0.068 & -0.251069 & 0.137322 \\
\hline \multirow{2}{*}{ KM2 } & 1 Domestic & 372 & 420.968 & 1.632 .528 & 0.084643 & \multirow[t]{2}{*}{6.674} & \multirow[t]{2}{*}{0.010} & -2.374 & 518 & 0.018 & -0.357890 & 0.150756 \\
\hline & 2 Foreign & 148 & 456.757 & 1.324 .030 & 0.108835 & & & -2.596 & 330.670 & 0.010 & -0.357890 & 0.137874 \\
\hline KM3 & 1 Domestic & 372 & 468.763 & 1.444 .296 & 0.074883 & 5.164 & 0.023 & 1.072 & 518 & 0.284 & 0.148445 & 0.138479 \\
\hline \multirow{2}{*}{ KM4 } & 1 Domestic & 372 & 459.341 & 1.522 .134 & 0.078919 & \multirow[t]{2}{*}{7.889} & \multirow[t]{2}{*}{0.005} & -1.173 & 518 & 0.241 & -0.166721 & 0.142171 \\
\hline & 2 Foreign & 148 & 476.014 & 1.301.451 & 0.106979 & & & -1.254 & 313.720 & 0.211 & -0.166721 & 0.132938 \\
\hline \multirow{2}{*}{ KM5 } & 1 Domestic & 372 & 456.093 & 1.564 .675 & 0.081125 & \multirow{2}{*}{3.784} & \multirow{2}{*}{0.052} & 0.046 & 518 & 0.963 & 0.006878 & 0.148611 \\
\hline & 2 Foreign & 148 & 455.405 & 1.435 .593 & 0.118005 & & & 0.048 & 292.863 & 0.962 & 0.006878 & 0.143201 \\
\hline \multirow[b]{2}{*}{ KM6 } & 1 Domestic & 372 & 445.609 & 1.631 .988 & 0.084615 & \multirow[t]{2}{*}{7.829} & \multirow[t]{2}{*}{0.005} & -1.770 & 518 & 0.077 & -0.265754 & 0.150110 \\
\hline & 2 Foreign & 148 & 472.185 & 1.298 .058 & 0.106700 & & & -1.952 & 337.188 & 0.051 & -0.265754 & 0.136178 \\
\hline \multirow[b]{2}{*}{ KM7 } & 1 Domestic & 372 & 486.713 & 1.459 .469 & 0.075670 & \multirow{2}{*}{9.747} & \multirow{2}{*}{0.002} & -0.308 & 518 & 0.758 & -0.041174 & 0.133605 \\
\hline & 2 Foreign & 148 & 490.830 & 1.133 .099 & 0.093140 & & & -0.343 & 345.462 & 0.732 & -0.041174 & 0.120004 \\
\hline \multirow{2}{*}{ KM9 } & 1 Domestic & 372 & 448.185 & 1.461 .607 & 0.075781 & 4.096 & 0.043 & -2.099 & 518 & 0.036 & -0.288415 & 0.137424 \\
\hline & 2 Foreign & 148 & 477.027 & 1.286 .215 & 0.105726 & & & -2.217 & 304.950 & 0.027 & -0.288415 & 0.130080 \\
\hline
\end{tabular}


Table 3. $t$-test of mean values of the knowledge management dimensions depending on the ownership structure (1-public; 2 -private).

\begin{tabular}{|c|c|c|c|c|c|c|c|c|c|c|c|c|}
\hline \multirow{2}{*}{$\begin{array}{c}\text { KM } \\
\text { Dimensions }\end{array}$} & \multirow{2}{*}{$\begin{array}{l}\text { Ownership } \\
\text { Structure }\end{array}$} & \multirow[b]{2}{*}{$\mathbf{N}$} & \multirow{2}{*}{ Mean } & \multirow{2}{*}{$\begin{array}{c}\text { Std. } \\
\text { Deviation }\end{array}$} & \multirow{2}{*}{$\begin{array}{l}\text { Std. Error } \\
\text { Mean }\end{array}$} & \multicolumn{2}{|c|}{$\begin{array}{c}\text { Levene's Test for } \\
\text { Equality of Variances }\end{array}$} & \multicolumn{5}{|c|}{$t$-Test for Equality of Means } \\
\hline & & & & & & F & Sig. & $t$ & df & $\begin{array}{c}\text { Sig. } \\
\text { (2-Tailed) }\end{array}$ & $\begin{array}{c}\text { Mean } \\
\text { Difference }\end{array}$ & $\begin{array}{l}\text { Std. Error } \\
\text { Difference }\end{array}$ \\
\hline \multirow{2}{*}{ KM1 } & 1 Public & 99 & 4.06926 & 1.551338 & 0.155915 & \multirow[t]{2}{*}{0.883} & \multirow[t]{2}{*}{0.348} & -1.749 & 518 & 0.081 & -0.291102 & 0.166484 \\
\hline & 2 Private & 421 & 4.36037 & 1.475933 & 0.071933 & & & -1.695 & 142.651 & 0.092 & -0.291102 & 0.171709 \\
\hline \multirow[b]{2}{*}{ KM2 } & 1 Public & 99 & 3.95455 & 1.622688 & 0.163086 & \multirow[t]{2}{*}{1.383} & \multirow[t]{2}{*}{0.240} & -2.547 & 518 & 0.011 & -0.440941 & 0.173128 \\
\hline & 2 Private & 421 & 4.39549 & 1.532506 & 0.074690 & & & -2.458 & 141.964 & 0.015 & -0.440941 & 0.179376 \\
\hline \multirow{2}{*}{ KM3 } & 1 Public & 99 & 4.48081 & 1.355539 & 0.136237 & \multirow[t]{2}{*}{0.943} & \multirow[t]{2}{*}{0.332} & -1.278 & 518 & 0.202 & -0.203277 & 0.159084 \\
\hline & 2 Private & 421 & 4.68409 & 1.439794 & 0.070171 & & & -1.326 & 154.360 & 0.187 & -0.203277 & 0.153246 \\
\hline \multirow[b]{2}{*}{ KM4 } & 1 Public & 99 & 4.51515 & 1.586301 & 0.159429 & \multirow[t]{2}{*}{2.483} & \multirow[t]{2}{*}{0.116} & -0.950 & 518 & 0.343 & -0.155276 & 0.163476 \\
\hline & 2 Private & 421 & 4.67043 & 1.433410 & 0.069860 & & & -0.892 & 138.059 & 0.374 & -0.155276 & 0.174064 \\
\hline \multirow{2}{*}{ KM5 } & 1 Public & 99 & 4.45791 & 1.652035 & 0.166036 & \multirow[t]{2}{*}{1.437} & \multirow[t]{2}{*}{0.231} & -0.731 & 518 & 0.465 & -0.124827 & 0.170715 \\
\hline & 2 Private & 421 & 4.58274 & 1.498042 & 0.073010 & & & -0.688 & 138.355 & 0.492 & -0.124827 & 0.181379 \\
\hline \multirow[b]{2}{*}{ KM6 } & 1 Public & 99 & 4.46465 & 1.593153 & 0.160118 & \multirow[t]{2}{*}{0.483} & \multirow[t]{2}{*}{0.487} & -0.479 & 518 & 0.632 & -0.082859 & 0.173008 \\
\hline & 2 Private & 421 & 4.54751 & 1.538393 & 0.074977 & & & -0.469 & 144.072 & 0.640 & -0.082859 & 0.176803 \\
\hline \multirow[b]{2}{*}{ KM7 } & 1 Public & 99 & 4.83983 & 1.425985 & 0.143317 & \multirow[t]{2}{*}{0.667} & \multirow[t]{2}{*}{0.414} & -0.314 & 518 & 0.754 & -0.048195 & 0.153555 \\
\hline & 2 Private & 421 & 4.88802 & 1.362509 & 0.066405 & & & -0.305 & 143.057 & 0.761 & -0.048195 & 0.157953 \\
\hline \multirow[b]{2}{*}{ KM9 } & 1 Public & 99 & 4.44949 & 1.359012 & 0.136586 & 0.015 & 0.902 & -0.892 & 518 & 0.373 & -0.141360 & 0.158494 \\
\hline & 2 Private & 421 & 4.59086 & 1.432582 & 0.069820 & & & -0.922 & 153.462 & 0.358 & -0.141360 & 0.153397 \\
\hline
\end{tabular}




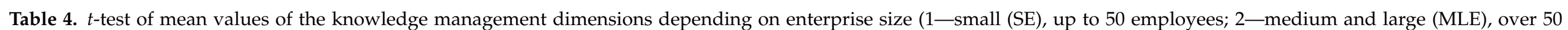
employees).

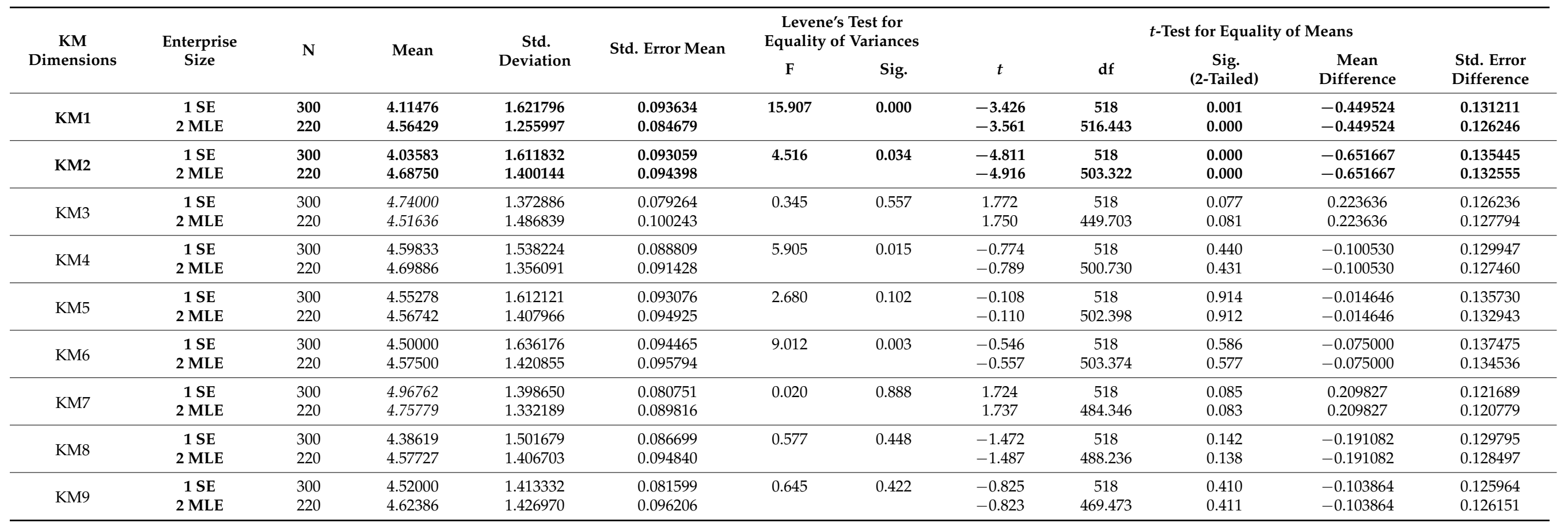




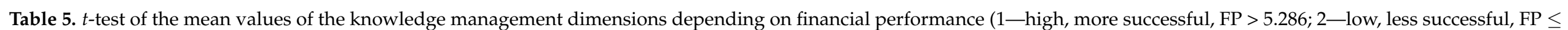
5.286).

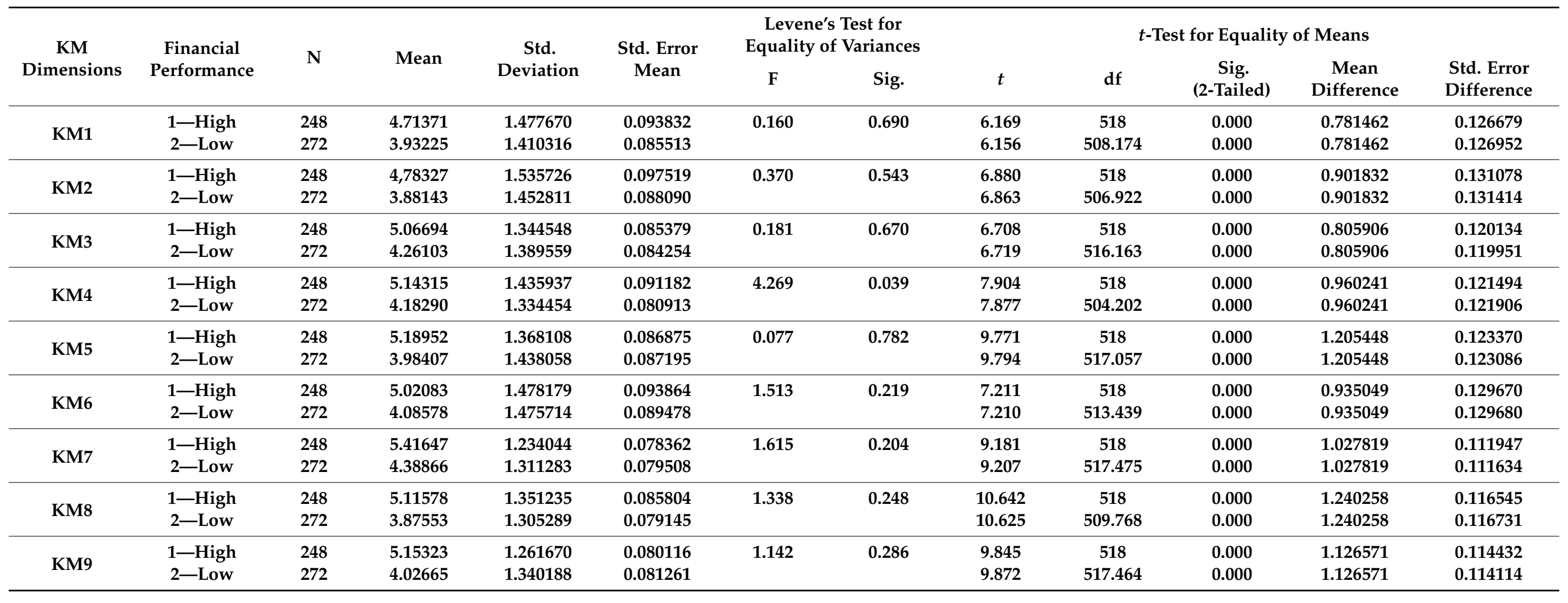


In this way, it was confirmed that there is a statistically significant difference in the influence of national origin of the enterprises as a control variable on knowledge management dimensions. Therefore, hypothesis $\mathrm{H} 2$ is confirmed.

4.4.2. The Influence of Ownership Structure on Knowledge Management Dimensions (Testing Hypothesis H3)

When the control variable is the ownership structure, a statistically significant difference in the mean values occurs in one dimension of knowledge management: KM2organizational culture. In this case, a higher mean value exists for private enterprises.

Private enterprises have an organizational culture which strongly supports knowledge management processes while work, training, learning, and knowledge transfer are valued to a greater extent. In private enterprises, senior management strongly supports knowledge management and employees better understand the role of knowledge and the role of learning in overall corporate success. Employees understand that they are expected to be more involved in the learning, knowledge transfer, and storage processes.

Additionally, it is concluded that organizational culture is responsible for the viability and development of organizations $[9,44]$. Existing research coincides with the conclusions that knowledge has to be present in all parts of the system as well as that organic organizational structure, decentralization, and low formalization have positive effects on employee intentions [46].

In the other eight dimensions of knowledge management, private enterprises also have higher mean values. The advantage is most pronounced in the dimension KM1organizational structure. However, even though there is no statistically significant difference in this dimension, the results are close to statistically significant. In this way, it is confirmed that there is a statistically significant difference in the impact of ownership structure of the enterprise as a control variable on one dimension of knowledge management. Therefore, hypothesis H3 is only partially confirmed.

\subsubsection{The Influence of Enterprise Size on Knowledge Management Dimensions (Testing} Hypothesis H4)

When the control variable is enterprise size, a statistically significant difference of the mean values occurs in two dimensions of knowledge management: KM1—organizational structure and KM2-organizational culture. In both cases, there are higher mean values for medium and large enterprises. Medium and large enterprises have organizational structures and organizational cultures which are more adapted to knowledge management. In medium and large enterprises, it is easier to form an organizational structure that affects knowledge management in a positive manner and makes it easier to find new knowledge, to create new knowledge, and to transfer and exchange knowledge. In addition, the organizational culture in medium and large enterprises has been established in a way that they more strongly understand, support, and more valuable knowledge management processes. It seems that the sheer size of these enterprises and the larger number of employees make it easier to create such conditions. Larger enterprises are not as flexible, but they make up for it with good organization, functional structures, well-established procedures, systemic problem solving, and systemic coping, with the challenges of environmental changes.

In five other dimensions of knowledge management, the mean values are uniform, with a slight advantage for medium and large enterprises. However, in two dimensions, the opposite influence of enterprise size as a control variable occurs. Small enterprises are better in the dimensions KM3 - T-shaped skills: human resources and KM7-knowledge application process. There is no statistically significant difference between these two dimensions, but the results are close to statistically significant. This phenomenon can be explained by the fact that small enterprises may not have an elaborate organizational structure and culture that is conducive to knowledge management but they have more flexible human resources and greater efficiency and effectiveness in applying knowledge. In these cases, it seems that enterprise size may be a limiting factor and that small enterprises have an advantage here. 
It can be argued that the results in the current paper are complementary with the results of other studies in this domain. Some of these studies confirm that knowledge management is more efficiently implemented in large enterprises [22,53,54]. In SMEs, a knowledge management infrastructure needs to be established to increase enterprise performance [22]. Similar studies state that the characteristics of the organizations, such as size, might influence the motivations, knowledge, and applicability of CE. As an example, research on the benefits of Environmental Management System (EMS) implementation pointed out that the perceived benefits are dependent on the organization size (bigger organizations more accustomed to alignment with business strategy and performance measurement, and smaller ones having more flexibility and less formality) [55].

In this way, it is confirmed that there is a statistically significant difference in the influence of enterprise size as a control variable on knowledge management dimensions. Therefore, hypothesis $\mathrm{H} 4$ is confirmed.

4.4.4. The Influence of Financial Performance on Knowledge Management Dimensions (Testing Hypothesis H5)

When financial performance is viewed as the control variable, a statistically significant difference in mean values occurs in all knowledge management dimensions. In all these cases, a higher mean value exists for enterprises with high financial performance.

Financial performance as a control variable has a complete impact on knowledge management dimensions. More successful enterprises have better quality and stronger knowledge management. This is a completely logical result. One can only consider whether quality knowledge management contributes to good financial performance or whether quality knowledge management is a consequence of enterprise success. The answer to this dilemma is that this relationship is mutual and that there is an interconnectedness between these constructs. In any case, high financial performance in an enterprise is a reliable indicator of successful knowledge management.

It is also important to note that high financial performance in an enterprise is a reliable indicator of successful knowledge management. These results are supported by other studies conducted in countries with a stable economy, where a strong link between financial performance and knowledge management implementation is noted [19-21]. These results are complementary to other similar studies in this domain. Some of these other studies confirm the relations between knowledge management, competitiveness, and financial indicators $[18,47]$; the relation between the process of knowledge application and financial performance $[17,23,33,56,57]$; as well as the relation between the process of knowledge protection and financial performance [58].

In this way, it is confirmed that there is a statistically significant difference in the influence of financial performance as a control variable on knowledge management dimensions. From here, hypothesis $\mathrm{H} 5$ is confirmed.

\section{Conclusions}

Knowledge management dimensions in Serbian enterprises have mean values that are slightly higher than the average, which is a good result when Serbia as a country in transition is taken into consideration. When other research conducted in the banking sector of Serbia are analyzed, it can be noticed that the transfer of knowledge is not very high [9]. Serbian enterprises may still not attach enough importance to knowledge management or do not understand its importance. However, there is high use of knowledge present in Serbian enterprises as well as quality human resources. The public sector of various developing countries has developed knowledge management functions to address the problem of low organizational commitment (higher turnover rates) and the performance of knowledge workers [20].

When knowledge management implementation is considered in developing countries, Serbia is not severely lacking behind. Knowledge management, in general, has higher values in foreign enterprises, private enterprises, medium and large enterprises, and financially stronger enterprises. These differences are most pronounced in two dimensions: 
KM1 - organizational structure and KM2-organizational culture. This indicates that the biggest differences in the level of knowledge management quality exist due to different approaches in knowledge management, different organizational attitudes and attitudes towards knowledge management, different degrees of understanding, and different support and evaluation of knowledge management. The differences in the obtained results can be due to the differences in the systematic approach to knowledge management at the organizational level. These conclusions are similar to the conclusions found in studies conducted in countries with stable economies and in other studies conducted in Serbia. The conclusions are that organizational understanding, evaluation, and adequate support in the process of knowledge transfer influence success indicators of knowledge transfer. Additionally, it is concluded that organizational culture is responsible for the viability and development of organizations $[9,20,44]$. Existing research coincides with the conclusions that knowledge has to be present in all parts of the system as well as that an organic organizational structure, decentralization, and low formalization have positive effects on employee intentions [46].

A slight deviation from these relations occurs in small enterprises where two dimensions (KM3-T-shaped skills: human resources and KM7-knowledge application process) have higher mean values compared to medium and large enterprises (but are not statistically significantly higher). This result indicates a tendency of small enterprises to sometimes have more flexible human resources and greater efficiency and effectiveness in applying knowledge. The necessity and importance of knowledge management is evident when the changing business environment is observed. Organizational sustainability relies on knowledge-based innovation, and enterprises have to innovate and create value through knowledge management in order to achieve a sustainable competitive position on the market. Previous studies conducted in countries with stable economies also point out that knowledge management is a key factor for organizational development. Knowledge management includes and brings constant competitive dynamics in the enterprise. These dynamics see knowledge as the basis for improving productivity [31]. The results of other studies also coincide with the conclusion that an organizational climate based on collaboration is an important factor for effective implementation of knowledge management practices. Also, managers have to establish an adequate organizational environment that would enable successful utilization of knowledge in enterprises. This would further significantly improve competitiveness on a macro level [30].

It is also important to note that high financial performance in an enterprise is a reliable indicator of successful knowledge management. These results are supported by other studies conducted in countries with a stable economy, where a strong link between financial performance and knowledge management implementation is noted [19-21].

It is quite clear that leaders and managers need to pay attention to all knowledge management processes in their organizations. A special recommendation for leaders and managers in domestic (Serbian) and state companies is to improve the organizational structure and organizational culture, so that they more strongly support knowledge management. Therefore, when knowledge management is improved, it also improves competitiveness and further affects the organizational sustainability.

The main limitation of this research is that the obtained results and proposed solutions are relevant for enterprises in Serbia. The results of the research refer to countries with specific transition conditions, both economies and economics. Additionally, it refers to the presence of psychological attitudes of people which are specific in such conditions. On the other hand, it has to be noted that a significant part of the research sample included foreign enterprises that operate in Serbia. This may imply a universality of the obtained results. Therefore, with a high degree of certainty, it is possible to assume that the analyzed phenomena and processes also exist in countries in which economic and social environments and characteristics of national culture are similar to the ones present in Serbia. However, it is uncertain to what extent this universality is applicable. For further directions in research, repeatability is recommended so that the results can be reevaluated and compared. In 
addition, it can be checked which relations and at what intensity the results coincide and differ. Since transition conditions are changing, i.e., countries are slowly coming out of transition, it is important to monitor these changes. From here, in accordance with these changes, new research can be conducted and recommended. It is also important to conduct similar research in other countries and to compare the obtained results.

Author Contributions: Conceptualization, M.N. and M.K.; methodology, D.R. and M.K.; software, M.K. and M.P.; validation, S.S. and M.K.; formal analysis, M.K. and M.N.; investigation, M.K. and S.S.; resources, S.S. and M.K.; data curation, M.N. and M.K.; writing-original draft preparation, M.K. and M.N.; writing-review and editing, M.K., M.P., M.N. and S.S.; visualization, M.K. and S.S.; supervision, D.R.; project administration, M.K. All authors have read and agreed to the published version of the manuscript.

Funding: Technical Faculty “Mihajlo Pupin”, Đure Đakovića BB. 23000 Zrenjanin, Serbia.

Informed Consent Statement: Not applicable.

Data Availability Statement: Data is contained within the article or supplementary material.

Acknowledgments: This research work was funded by Technical Faculty "Mihajlo Pupin", Đure Đakovića BB. 23000 Zrenjanin, Serbia.

Conflicts of Interest: The authors declare no conflict of interest.

\section{References}

1. Zimon, D.; Tyan, J.; Sroufe, R. Drivers of sustainable supply chain management: Practices to alignment with un sustainable development goals. Int. J. Qual. Res. 2020, 14, 232-234. [CrossRef]

2. Melnyk, S.A.; Sroufe, R.P.; Calantone, R. Assessing the impact of environmental management systems on corporate and environmental performance. J. Oper. Manag. 2003, 21, 329-351. [CrossRef]

3. Fonseca, L.M.; Domingues, J.P.; Pereira, M.T.; Martins, F.F.; Zimon, D. Assessment of Circular Economy within Portuguese Organizations. Sustainability 2018, 10, 2521. [CrossRef]

4. Ghisellini, P.; Cialani, C.; Ulgiati, S. A review on circular economy: The expected transition to a balanced interplay of environmental and economic systems. J. Clean. Prod. 2016, 114, 11-32. [CrossRef]

5. Rizos, V.; Behrens, A.; Van der Gaast, W.; Hofman, E.; Ioannou, A.; Kafyeke, T.; Flamos, A.; Rinaldi, R.; Papadelis, S.; HirschnitzGarbers, M.; et al. Implementation of Circular Economy Business Models by Small and Medium-Sized Enterprises (SMEs): Barriers and Enablers. Sustainability 2016, 8, 1212. [CrossRef]

6. Van Buren, N.; Demmers, M.; van der Heijden, R.; Witlox, F. Towards a Circular Economy: The Role of Dutch Logistics Industries and Governments. Sustainability 2016, 8, 647. [CrossRef]

7. Bakator, M.; Đorđević, D.; Ćoćkalo, D.; Bogetić, S. The imapct of consumer-company relationships on brand loyalty. Manag. J. Sustain. Bus. Manag. Solut. Emerg. Econ. 2020, 25, 53-64. [CrossRef]

8. Lice, A.; Striedinger, A.; Scholz, C.; Mac Sithigh, D.; Fenech, J.; Miklavic, K.; Geven, K.; Stambolieva, M.; Haslinger, S. The Lisbon Agenda; ESIB-The National Unions of Students in Europe: Bruxelles, Belgium, 2006.

9. Tornjanski, V.; Petrovic, D.; Nesic, S. Effectiveness of knowledge transfer between project team members in digitally disrupted organizations. Manag. Sustain. Bus. Manag. Solutions Emerg. Econ. 2019, 25, 1-14. [CrossRef]

10. Đukić, G.; Ilić, B. Održivost u visokom obrazovnju-poređenje Azijsko Pacifičkog regiona i Srbije. Trendovi u Poslovanju 2020, 1 , 9-21. [CrossRef]

11. Jennex, M.E.; Olfman, L. A model of knowledge management success. Int. J. Knowl. Manag. 2006, 2, 51-68. [CrossRef]

12. Debowski, S. Knowledge Management; John Wiley \& Sons: Milton, Queensland, Australia, 2006.

13. Wiig, K.M. What future knowledge management users may expect. J. Knowl. Manag. 1999, 3, 155-165. [CrossRef]

14. Echeverry, C.; Herrera, O.; Velez, A. Knowledge management from the organizational culture in call centers in Manizales. Cuad. Adm. 2019, 35, 15-25. [CrossRef]

15. Sanchez, V. Self-employment, Knowledge and Economic Growth: An empirical study for Latin American countries. Contemp. Econ. 2018, 12, 473.

16. Dang, C.; Le-Hoai, L.; Kim, S.-Y. Impact of knowledge enabling factors on organizational effectiveness in construction companies. J. Knowl. Manag. 2018, 22, 759-780. [CrossRef]

17. Lee, K.; Lee, S.; Kang, I. KMPI: Measuring knowledge management performance. Inf. Manag. 2005, 43, 469-482. [CrossRef]

18. Zebal, M.; Ferdous, A.; Chambers, C. An integrated model of marketing knowledge-a tacit knowledge perspective. J. Res. Mark. Entrep. 2019, 21, 2-18. [CrossRef]

19. Mageswari, S.; Sivasubramanian, R.; Dath, T. A comprehensive analysis of knowledge management in Indian manufacturing companies. J. Manuf. Technol. Manag. 2017, 28, 506-530. [CrossRef] 
20. Razzaq, S.; Shujahat, M.; Hussain, S.; Nawaz, F.; Wang, M.; Ali, M.; Tehseen, S. Knowledge management, organizational commitment and knowledge-worker performance: The neglected role of knowledge management in the public sector. Bus. Process Manag. J. 2019, 25, 923. [CrossRef]

21. Najmi, K.; Kadir, A.; Kadir, M. Mediation effect of dynamic capability in the relationship between knowledge management and strategic leadership on organizational performance accountability. Int. J. Law Manag. 2018, 60, 517-529. [CrossRef]

22. Lee, C.; Ho, C.; Chiu, Y. The impact of knowledge management enablers on non-financial performance in small and medium enterprises. Int. J. Technol. Manag. 2008, 43, 266-283. [CrossRef]

23. Chen, C.; Huang, J. Strategic human resource practices and innovation performance-The mediating role of knowledge management capacity. J. Bus. Res. 2009, 62, 104-114. [CrossRef]

24. Mondal, A.; Ghosh, S. Intellectual capital and financial performance of Indian banks. J. Intellect. Cap. 2012, 13, 515-530. [CrossRef]

25. Maditinos, D.; Chatzoudes, D.; Tsairidis, C.; Theriou, G. The impact of intellectual capital on firms' market value and financial performance. J. Intellect. Cap. 2011, 12, 132-151. [CrossRef]

26. Prieto, I.; Revilla, E. Learning capability and business performance: A non-financial and financial assessment. Learn. Organ. 2006, 13, 166-185. [CrossRef]

27. Joshi, M.; Cahill, D.; Sidhu, J.; Kansal, M. Intellectual capital and financial performance: An evaluation of the Australian financial sector. J. Intellect. Cap. 2013, 14, 264-285. [CrossRef]

28. Kianto, A.; Andreeva, T.; Pavlov, Y. The impact of intellectual capital management on company competitiveness and financial performance. Knowl. Manag. Res. Pract. 2013, 11, 112-122. [CrossRef]

29. Hsu, H.-Y.S. Knowledge Management and Intellectual Capital. Ph.D. Thesis, Southern Illinois University, Carbondale, IL, USA, 2006.

30. Darroch, J. Knowledge management, innovation and firm performance. J. Knowl. Manag. 2005, 9, 101-115. [CrossRef]

31. Jokanović, B.; Zivlak, N.; Okanović, A.; Ćulibrk, J.; Duđak, L. The Model of Knowledge Management Based on Organizational Climate. Sustainability 2020, 12, 3273. [CrossRef]

32. Kovačević, M.; Blagojević, S.; Kuzmanović, B. Sustainability of the Motivation Policy Model for Employees in State Administration. Sustainability 2020, 12, 7974. [CrossRef]

33. Abbas, J.; Sagsan, M. Impact of knowledge management practices on green innovation and corporate sustainable development: A structural analysis. J. Clean. Prod. 2019, 229, 611-620. [CrossRef]

34. Manovas, M. Investigating the Relationship between Knowledge Management Capability and Knowledge Transfer Success. Master's Thesis, Concordia University, Montreal, QC, Canada, 2004.

35. Smith, T. Knowledge Management and Its Capabilities Linked to the Business Strategy for Organisational Effectiveness. DBA Thesis, Nova Southeastern University, Fort Lauderdale, FL, USA, 2006.

36. Khalifa, M.; Liu, V. Knowledge management effectiveness. In Proceedings of the 4th European Conference on Knowledge Management, Oxford, UK, 18-19 September 2003.

37. Cugueró-Escofet, N.; Ficapal-Cusí, P.; Torrent-Sellens, J. Sustainable Human Resource Management: How to Create a Knowledge Sharing Behavior through Organizational Justice, Organizational Support, Satisfaction and Commitment. Sustainability 2019, 11, 5419. [CrossRef]

38. Porter, M.E. Competitive Advantage: Creating and Sustaining Superior Performance; Free Press: New York, NY, USA, 1985 ; Volume 13.

39. Cascella, V. Effective strategic planning. Qual. Prog. 2002, 35, 62-67.

40. Gold, A.; Malhotra, A.; Segars, A. Knowledge management: An organizational capabilities perspective. J. Manag. Inf. Syst. 2001, 18, 185-214. [CrossRef]

41. Lee, H.; Choi, B. Knowledge management enablers, processes, and organizational performance: An integrative view and empirical examination. J. Manag. Inf. Syst. 2003, 20, 179-228.

42. Zack, M.H. Developing a knowledge strategy. Calif. Manag. Rev. 1999, 41, 125-145. [CrossRef]

43. Zheng, W.; Yang, B.; McLean, G.N. Linking organisastional culture, structure, strategy, and organizational effectiveness: Mediating role of knowledge management. J. Bus. Res. 2010, 63, 763-771. [CrossRef]

44. Raudeliūnienè, J.; Tvaronavičienė, M.; Blažytė, M. Knowledge Management Practice in General Education Schools as a Tool for Sustainable Development. Sustainability 2020, 12, 4034. [CrossRef]

45. Milosavljević, M.; Milanovic, N.; Benkovic, S. Drivers of Performance Measurement Use: Empirical Evidence from Serbia. Manag. Sustain. Bus. Manag. Solutions Emerg. Econ. 2016, 21, 33-43.

46. Eric-Nielsen, J.; Babic, V.; Aleksić, V.S.; Nikolić, J. Driving Forces of Employees' Entrepreneurial Intentions-Leadership Style and Organizational Structure. Manag. Sustain. Bus. Manag. Solutions Emerg. Econ. 2019, 24, 59-71. [CrossRef]

47. Krstić, M.; Filipe, J.A.; Chavaglia, J. Higher Education as a Determinant of the Competitiveness and Sustainable Development of an Economy. Sustainability 2020, 12, 6607. [CrossRef]

48. Lopez, S.; Peón, J.; Ordás, C. Organizational learning as a determining factor in business performance. Learn. Organ. 2005, 12, 227-245. [CrossRef]

49. Nguyen, T.N.Q. Knowledge Management Capability and Competitive Advantage: An Empirical Study of Vietnamese Enterprises. Ph.D. Thesis, Southern Cross University, Lismore, NSW, Australia, 2010.

50. Tan, J.J.; Litsschert, R.J. Environment-strategy relationship and its performance implications: An empirical study of the Chinese electronics industry. Strateg. Manag. J. 1994, 15, 1-20. [CrossRef] 
51. Wang, D.; Tsui, A.S.; Zhang, Y.; Ma, L. Employment relationships and firm performance: Evidence from an emerging economy. J. Organ. Behav. 2003, 24, 511-535. [CrossRef]

52. Wang, H.; Tsui, A.S.; Xin, K.R. CEO leadership behaviors, organizational performance, and employees' attitudes. Leadersh. Q. 2011, 22, 92-105. [CrossRef]

53. Wong, K. Critical success factors for implementing knowledge management in small and medium enterprises. Ind. Manag. Data Syst. 2005, 105, 261-279. [CrossRef]

54. Liu, G.; Ren, H. Organizational learning and job satisfaction of trainee auditors: A case study of Chinese CPA firms. Account. Res. J. 2019, 32, 70-87. [CrossRef]

55. Fonseca, L.M.; Domingues, J.P. Exploratory Research of ISO 14001:2015 Transition among Portuguese Organizations. Sustainability 2018, 10, 781. [CrossRef]

56. Imran, M.; Bilal, A.; Aslam, U.; Rahman, U. Knowledge management strategy: An organizational change prospective. J. Enterp. Inf. Manag. 2017, 30, 335-351. [CrossRef]

57. Zack, M.; McKeen, J.; Singh, S. Knowledge management and organizational performance: An exploratory analysis. J. Knowl. Manag. 2009, 13, 392-409. [CrossRef]

58. Huang, Y.; Yan, A.; Smith, R. Methodology for the Development of Knowledge Management on Organizational Performance Based on Employees' Professional Competence. Rev. Cercet. Si Interv. Sociala 2019, 64, 85. [CrossRef] 